\title{
The Determinants of Inflation in Ethiopia: A Multivariate Time Series Analysis
}

\author{
Girma Mulugeta Emeru( Masters in development Economics) \\ Lecturer, School of Economics, Debre Birhan University, Debre Birhan, Ethiopia
}

\begin{abstract}
Inflation is a continuous increase in the general price level in an economy and falling of purchasing power of the monetary unit. In Ethiopia inflation was not generally an issue before the year 2003/04. Different studies point out their own reasons for the dynamics of inflation of the state. Generally, the aim of this paper to identifying the major sources of inflation. The study observed CPI and its components annually from 1970 to 2011. To identify the major sources of inflation in Ethiopia, the study presented, a VAR, co-integration analysis and the VECM allied with the descriptive analysis. The result of the VECM showed, only budget deficit as percentage of GDP is positively determining inflation of Ethiopia in the short run. In the short run the Broad Money Supply, Real GDP, the imported inflation of international petroleum price and the nominal exchange rate has insignificant effect of the annual Ethiopia's price hike. In the long run, the Ethiopia's inflation mainly driven by the Broad Money supply, the Real GDP, interest rate, the Nominal Exchange Rate, and the budget deficit with high significance level. The Broad Money Supply in the economy and the Banks and Financial institutions average lending rate has a positive long run effect on inflation. While, the Rainfall, the deficit budget and the Nominal Exchange rate has a negative long run determination of the price level in Ethiopia. Therefore, the government should follow planned government expenditure and by allowing the Banks and financial institutions lending rate determination should hold on the hand of the market rather than the government to curb inflation in Ethiopia.
\end{abstract}

Keywords: VECM , Inflation, Ethiopia

DOI: $10.7176 / \mathrm{JESD} / 11-21-06$

Publication date: November $30^{\text {th }} 2020$

\section{INTRODUCTION}

\subsection{BACKGROUND OF THE STUDY}

Inflation is a continuous increase in the general price level in an economy and falling of purchasing power of the monetary unit, in Ethiopia the birr. Inflation mainly hurts lower income brackets, lenders and savers and benefiting capital owners and borrowers in short period but in the long run they may burden when an economy output growth may curbed by inflation.

When the price level rises, each unit of currency buys fewer goods and services; consequently, inflation is also erosion in the purchasing power of money, a loss of real value in the internal medium of exchange and unit of account in the economy (Walgenbach et al., 1973).

Worldwide inflation is recently rising, For instance in the year 2009 World, Emerging and Developing, and Sub Saharan Africa -inflations were 2.3\%, 5.5\% \& 9.5\%, but in August 2011 it increased to 4.9\%, 7.6\% and $11 \%$ respectively (IMF, 2011)

In the context of developing countries, economic stabilization usually refers to a program comprehensive economic measures designed to achieve a broad macroeconomic goals such as sustained improvement in balance of payment, a reduction in domestic inflation, or some combination of the two (Khan M.S. and Knight M.D.,1982)

For Ethiopia, economic growth is not a matter of choice; we must maintain higher growth to provide our present or future generations need (Teshome A., 2011). I am not forwarding the impact of economic growth on the extraordinary surge of Ethiopia recent inflation rather identifying the sources.

\subsection{STATEMENT OF THE PROBLEM}

In Ethiopia inflation was not generally an issue before the year 2003/04. The country has not suffered from high inflation prior to 2004 and annual average inflation was only 5.2 percent during 1980/81-2003/04. The major hikes in the general price level occurred during war and drought times. The highest inflation episodes of 18.2, 21.1 and 15.5, respectively, occurred in 1984/85 due to severe drought, in 1991/92 at the peak of war, and in 2003 following drought (Loening et al., 2009). However in the post 2002/03 period inflation began to appear as a major problem following the government's move towards less conservative monetary and fiscal policy and the state activism in the economy breaking the institutional legacy macro policy conservatism (Alemayehu G. and Kibrom T., 2008). Before the period when price jumps the above evidences shows that, the sources of inflation in Ethiopia is mainly associated with structural bottlenecks such as agricultural output constraints. This indicates that after the period 2002/03 the source swings its archetype to monetary phenomena.

Generally, over the last nine years; i.e. during 2004-2012. The economy has registered rapid growth. Accordingly, in this period the annual average growth rate of GDP was 11 percent. The agriculture, industry and 
service sectors' annual average growth was $9.6 \%, 11.1 \%$ and $12.7 \%$ respectively (MoFED, 2012). In the country the construction of infrastructures such as roads, dams and light city railways are expanding. These Constructions might increase the government expenditure and domestic tax revenue has also increased but not as much the expenditure. This creates a fiscal deficit. One way of filling the deficit is increasing the money stock in the economy. The country experience on average low inflation rate it was hot-blooded. This implies inflation has become the dominant current macroeconomic problem.

These studies hold up and fortify the statement that the source of inflation in Ethiopia not in synchronization. Therefore the study has an advance for clear strength of mind the major spring of inflation in Ethiopia. In addition due to the vibrant nature of the variable, price level, the sources also dynamic hence it is necessary to study this issue more recurrently and opportune.

In most of the time, the sources of price increases are whether a monetary variables or structural conditions influences prices in developing countries, like Ethiopia. Price in Ethiopia has, on the whole been very stable irrespective of monetary policy stance of different regimes that ruled the country. During Derg period, money supply was consistently increased at more than the double rate of growth of nominal GDP while inflation kept at very low levels. High inflation periods during this time were largely associated with structural shocks such as severe drought (1984/85) and 2002/03 or political instability (1990/91) when inflation reached digits (EEA, 2001).

After 2003/04 as (Alemayehu G. \& Kibrom T., 2008) declared that the paradigm is shifting to monetary situation. The study was addressed which condition is best describes the trend of inflation in Ethiopia.

The adverse economic impact of oil price shock on oil importing developing countries is greater than developed countries (Birouk T. et al., 2010). In Ethiopia, annual general inflation at the national level reached a peak of 64 percent in July 2008 and then come down in 2009 and early 2010 (EEA, 2012). The information indicates some linkage between the international petroleum price and inflation in Ethiopia. This study addressed the imported inflation have a significant effect on domestic price level, by serving international petroleum price as proxy variable.

Generally previous research outputs on Ethiopia have used only the overall consumer price indexes to model and forecast the rate of inflation. The aim of this research is to investigate inflation in Ethiopia by explicitly modeling food and non-food price index, as well as by including variables like money supply, soaring oil price, war expenditure (Eritrea), nominal exchange rate and GDP variables that other researchers forgotten by applying a vectoregressive (VAR) model.

\subsection{THE OBJECTIVE OF THE STUDY}

\subsubsection{The General objective of the study}

The general objective of the study is to identify and analyze the determinants of inflation in Ethiopia.

\subsubsection{The Specific objective of the study}

Specifically this study gives consideration for the following issues:

- To identify the sources of price increases are whether a monetary variable or structural conditions.

- To measure the significance of imported inflation for the soaring of domestic price level between the periods 1970 to 2011 .

- To identify the devaluation of the exchange rate by NBE is an important factor for the dynamics of inflation in Ethiopia.

\section{RELATED LITRATURE REVIEW}

\subsection{DEFINITIONS AND MEASURES OF INFLATION}

Generally, inflation has been defined either as a phenomenon of rising prices, or as a monetary phenomenon. Definitions given by the economists like Crowther (1958), Gardner Ackley (1961), and H.G. Johnson (1972) regard inflation as a phenomenon of rising prices. According to Crowther (1958, pp: 197), inflation is a "state in which the value of money is falling, i.e., the prices are rising." In the words of Gardner Ackley (1961, pp: 502), "Inflation is a persistent and appreciable rise in the general level or average of prices." Harry G. Johnson (1972, pp: 9) states, "I define inflation as substantial rise in prices."

Economists like, Hawtrey (1928), Kemmerer (1942), Friedman and Schwartz A. (1968), Coulborn (n.d.) define inflation as a monetary phenomenon. Hawtrey (1928) defines inflation as the "issue of too much currency."According to Kemmerer (1942), "Inflation is too much money and deposit currency, that is, too much currency in relation to the physical volume of business being done."

According to Friedman and Schwartz (1968), "Inflation is always and everywhere a monetary phenomenon." Coulborn (n.d.) defines inflation as "too much money chasing too few goods."

Keynes (1940) defined inflation as a phenomenon of full employment. According to him, inflation is the result of the excess of aggregate demand over the available aggregate supply and true inflation starts only after full employment. 


\subsubsection{The Structuralist explanation of inflation}

The emergency of the structuralist schools in late 1950's and early 1960's is often associated with the inflationary process of Latin American countries, which took place during the post war II. They argued that inflation is caused by structural limitation propagation mechanism in their explanations.

In order for inflation to takes place the structuralists argue that there must be propagation mechanisms. Concerning developing countries, the structuralist further identified the following commonly observed basic structural bottlenecks that lead to inflationary process. According to Teslim (1982) the first constraint is agricultural constraints:-Most developing countries are characterized by high population growth rate that results in increasing demand for food. This increased demand in turn pushes the food price up ward. For him the second constraint is Foreign Trade Constraints: - In most least developed countries export receipts are slowly increasing while import expenditure are rapidly increasing. This is often ascribed to the falling demand for LDC's export items and rapidly rising demand for import items in LDC's. This results in foreign exchange constraints and persistent balance of payment deficit. The final constrain is Budget constraints: - Budget Constraints that most LDC's face are among the structural rigidities accountable for inflationary process ( Barungi , 1997 , Kotwal , 1987) .

\subsubsection{The monetarists Explanation of inflation.}

The monetarist theory of inflation is basically the result of the new quantity theory of money forward by Milton Friedman (1969) and his followers. The new quantity theory of money differ from the old theory is that, it is theory of demand for money, which is expressed by optimum relation between the stock of money and the stock of other assets.

\section{EMPERICAL REVIEW}

A number of studies were tried to find the main determinants of inflation in developing world. For instance, (IMF, 2001, 2005, 2008); and AfDB, (2011) finding on inflation mainly focused on LDC's.

In Asia also different studies conducted to determine the inflationary factors. According to C. O. and D. F. Unsal (2011) tried to investigate inflation in Vietnam. They studied the nature of inflation in Vietnam over the period 1900-2007. According to Thanh B.K.T., (2008); analysis the output growth has played an important role on causing inflation. The former study used standardized coefficients to determine the factors affecting inflation in Vietnam. While the later, investigate the dynamics of inflation in Asia.

In Africa Dellamini A. et.al. (2001); Laryea S.A. and Sumalia U.R. (2001); Bayo F.,(2004); AfDB (2011) investigated the determinants of inflation in Africa. According to Dellamini A.(2001) he tried to determine the determinant of inflation in Swaziland from 1974-2000. The determinants in Swaziland were modeled by the cointegration analysis and the Error Correction Model. The output of the study indicated that money supply is insignificant to explain inflation but budget deficit and interest rate. The key factor for Swaziland inflation as the study was exchange rate devaluation, used common currency with Republic of South Africa. Therefore, the condition is monetary than structural.

Bayo F. (2004) investigated inflation determinants in Nigeria from 1981 to 2003. The study used OLS to identifying the factors determining the price level in Nigerian economy. The study forwarded that monetary conditions are the key determinants of inflation in Nigeria. But the model OLS does not capture the feedback relationship among the variables and there very short sample size. This may create biased and inconsistent output leads to wrong policy recommendation.

Now I will turn to study area, Ethiopia. In Ethiopia, comparing the seriousness of the problem and the studies on the issue, I found the studies are very small. However, the study tried to review some important empirical assessments on determining the inflation episode in Ethiopia among the few works. (Alemayehu G. and Kibrom T.,2008 ), short run and long run model, the VAR was employed on food and non-food sectors for short run analysis and Single error correction model is applied to analyze the long run relationship. The most important determinants of inflation in the long run in the study are mainly domestic monetary developments while cost push factors are the forces behind short run inflation.

Another studies by Seifu N.(2011) ;Solomon M., (2012) and modeling the inflation phenomena of Ethiopia applied the VAR approach. Seifu N.(2011) observed monthly from January 2000 up to December 2010. In his study modeling CPI with food and non-food indices and the output was on average high power to explain the inflationary condition of Ethiopia. One critiques here is that, the problem has began in 2002 so it is incomparable period to definitely talking the trend of inflation because many studies forwarded there is different form of determinants of inflation in Ethiopia. However, minimum number of variables became the study efficient and the methodology he used gave him the expected outcomes.

Solomon (2012) assessed the determinants of inflation over the period 1970 to 2010. By his rigorous parametric analysis, reached on the points that, in the long run, broad money supply growth, large fiscal deficit and real GDP are the key determinants of the change in CPI, real effective exchange rate and the expected inflation are either statistically insignificant or have marginal economic impacts on inflation. While fiscal deficit and real effective exchange rate are insignificant in the short run. But in the short run the main determinant of inflation in 
developing economies is printing money due to large fiscal deficit rather than bond selling.

The above all empirical evidences supports that there is no consensus on why Ethiopia is experiencing such rapid prices rise. Inflation growth has recently coincide with high economic growth rate, whereas in the past inflation was traditionally associated with large agricultural supply shocks due to drought. Whatever, all studies reviewed above may serve as an input to find a lost key in light direction than the dark one, not by intuition rather VAR econometric analysis.

\section{METHODOLOGY}

\subsection{DATA SOURCES}

The data used throughout this paper is only annual secondary data spanning from 1970 up to 2011 . The data for the study collected from world bank. Many economic time series have characteristics incompatible with the stationary data. However, in some cases simply transformation can move the series closer to stationary. In such cases, logarithmic transformation may help to stabilize the variance (Lütkephohl H., 2004).

\subsection{METHODOLOGY OF THE STUDY}

To meet to identify the major determinants of inflationary pressure in Ethiopia, the present paper employed both the descriptive analysis and the econometric model. Priori, The international petroleum price considered in the model as an exogenous variable due to the insignificant power of the country to determine the international market prices. The Exchange rate of Ethiopia against US dollar is determined in the model as an endogenous variable. The major Ethiopian inflation determinants modeled with the VAR approach. The VAR is assuming the variables within the model are endogenous. But the VAR may not extended after determining the series weather its stationary or not by both ADF tests. If the variables are integrated of the same order I (1) they are stationary of integrated of order one it is better to find there linear combination of the non stationary variable which is stationary, efficient estimate. This is possibly done by co-integration analysis of determining there long run relationship by identifying the equations using the Johansen approach. Afterward, these stationary series integrated of order one is corrected by the so called VECM. I will discuss in brief the detail of the methodology I follow in this study.

\subsubsection{Vector Autoregressive Model}

Vector auto regression (VAR) is a statistical model used to capture the linear interdependencies among multiple time series. VAR models generalize the univariate Autoregressive(AR) models by allowing for more than one evolving variable. A natural starting place for multivariate models is to treat each variable symmetrically.

\subsubsection{THE STATIONARITY TEST}

Stationary of a series is an important phenomenon because it can influence its behavior. To avoid the spurious regression problem that may arise from regressing a non-stationary time series on one or more non-stationary time series, we have transforming non-stationary time series make them stationary. The transformation method depends on whether the time series are differencing stationary process (DSP) or trend stationary process(TSP) as (Gujarati, 2004) .

\subsubsection{The ADF TEST OF UNIT ROOT}

It is an augmented version of the Dickey and Fuller (1979) test for a larger and more complicated set of time series models. The augmented Dickey-Fuller (ADF) statistic, used in the test, is a negative number. The more negative it is, the stronger the rejection of the hypothesis that there is a unit root at some level of confidence.

Once a value for the test statistic is computed it can be compared to the relevant critical value for the DickeyFuller Test. If the test statistic is less (this test is non symmetrical so we do not consider an absolute value) than (a larger negative) the critical value, then the null hypothesis of is rejected and no unit root is present.

\subsubsection{JOHANSEN COINTEGRATION TEST}

Johansen, s. and K. Juselius, (1990) procedures used two test to determine the number of co integrating vector: the Maximum Eigen value test and the Trace test. This study employed both procedures of Johansen co-integration test. In some cases Trace and Maximum Eigenvalue statistics may yield different results and (Alexander, C., 2001) indicates that in this case the result of trace test should be preferred.

\subsubsection{THE VECM}

If cointegration has been detected between series we know that there exists a long term equilibrium relationship between them so we apply VECM in order to evaluate the short run properties of cointegrated series. In case of no cointegrating VECM is no longer required. A negative and significant coefficient of the VECM indicates that any short-term fluctuations between the independent variables and the dependent variable will give rise to a stable long relationship between the variables.

\section{RESULTS AND DISCUSSIONS}

\subsection{AN OVERVIEW OF ETHIOPIA'S INFLATION FROM 1970-2011}

In Ethiopia, general prices are driven mainly by the movement in food price in which make up 57 percent of the weight in consumption basket. Thus, the, most of volatility is explained by the movement in food prices (see Fig. 
4.1 below). According to(EEA,2012) among food items Cereals has the biggest share but other food items including coffee, fats and oils, pulses and spices recorded high inflation have low share in household expenditure.

Fig. 4.1 the General, Food and non food inflation rate of Ethiopia, 1970-2011

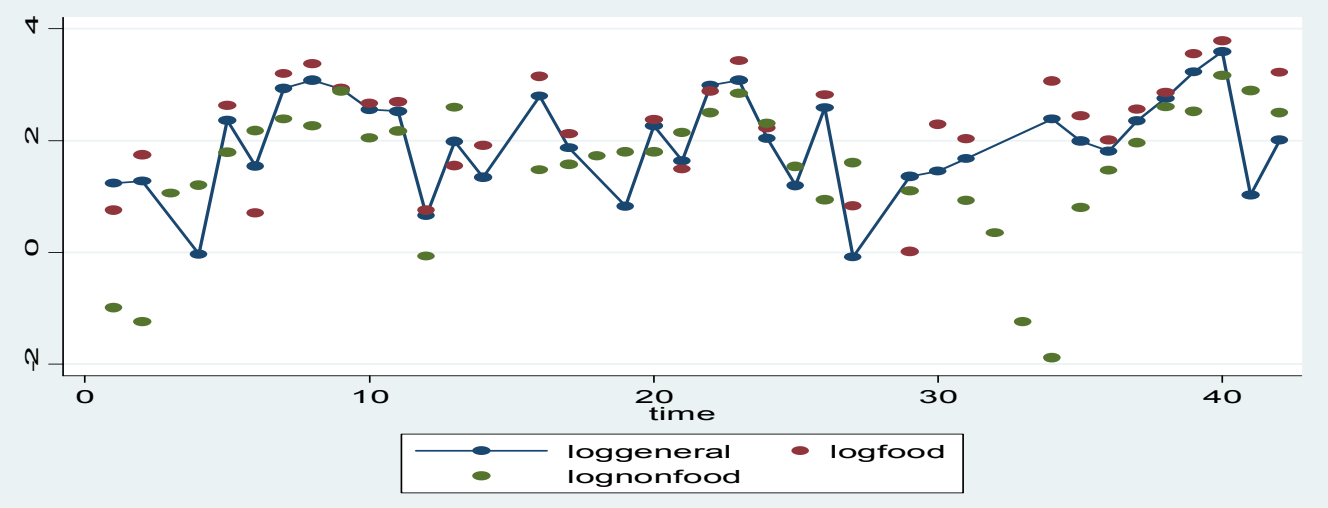

The figure 4.1 above provides us with some clues as to why the general price level of the economy has been rising recently, especially over the last eight years of the study period. The general and the food price movement of the Ethiopian economy is almost side by side. This shows the food price skyrocketing so does- the general price level.

\subsection{RELATIONSHIP BETWEEN INFLATION AND SOME MACROECONOMIC VARIABLES IN ETHIOPIA FROM 1970-2011}

The process of inflation implies interaction between various macro economic variables. The present research paper has considered four important macroeconomic variables. These are the growth rate of money supply, the growth rate of Real GDP, the Nominal exchange rate and the petroleum price in international market, proxy to imported inflation.

\subsubsection{INFLATION AND MONEY SUPPLY GROWTH}

The trend of inflation rate and money supply growth in the economy showed below (Figure 4.2.)

Figure 4.2. Money growth and Inflation rate in Ethiopia, 1970-2011.

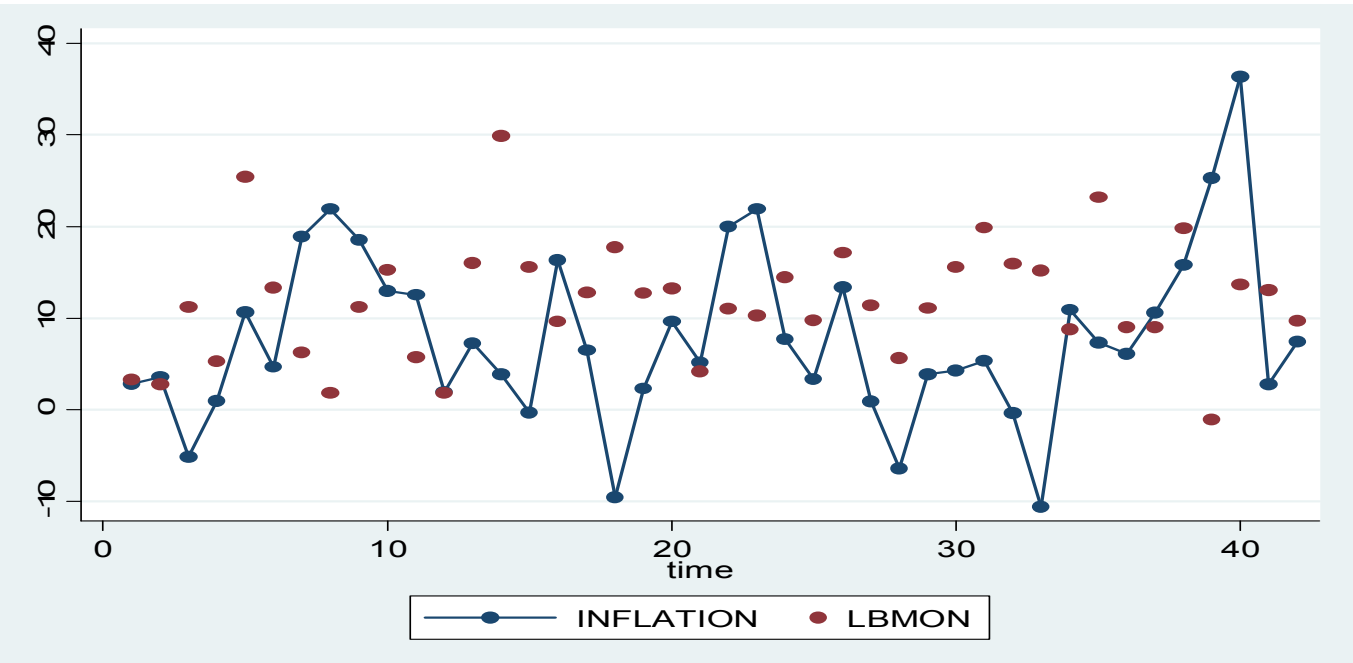

From the above trend monetary factor played a key role in driving the inflation rate in Ethiopia.

\subsubsection{INFLATION AND REAL GDP}

Inflation seems keeping in line with Real GDP growth .The paradox between inflation and Real GDP growth has not clear theoretical base. The higher economic growth attached with higher and inflation rate (see figure 4.2). 
Figure 4.3. Inflation and growth rate of Real GDP in Ethiopia, 1970-2011

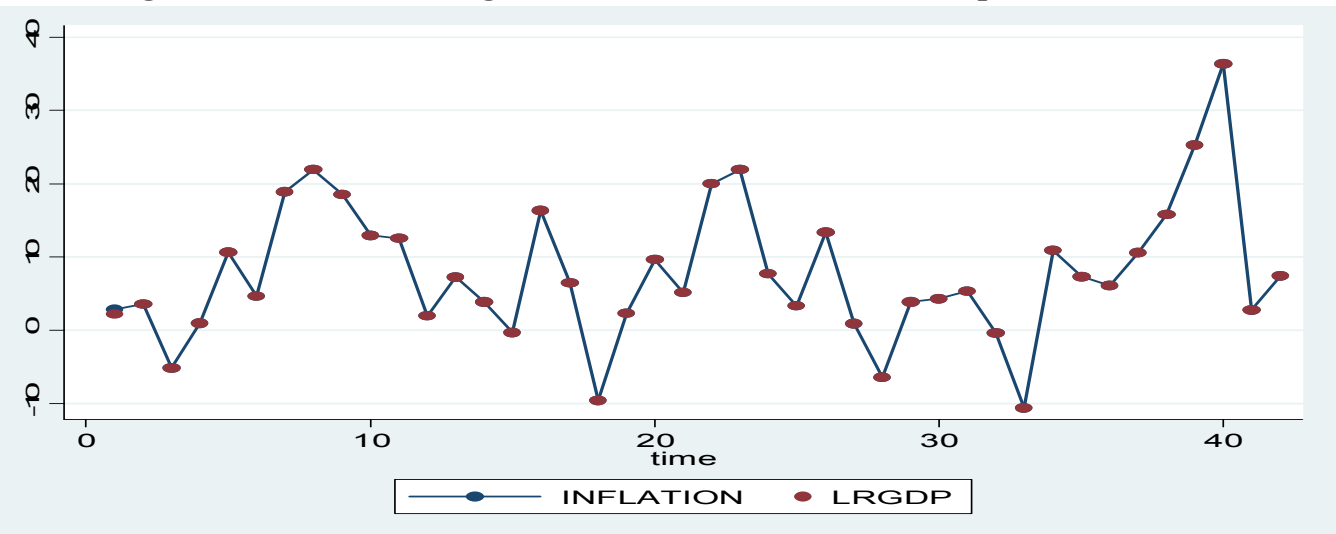

\subsubsection{INFLATION AND NOMINAL EXCHANGE RATE}

Devaluation of the birr is likely to aggravate inflation and it could start a snowball effect of higher inflation as it can build into a cascade of expectations for further devaluation by private citizens. In Ethiopia, the Birr (ETB) has been declining in its value for the past several years now. During the past regimes the exchange rate was less faltering while the inflation rate is vacillated. For instance, in the Derg regime (1974 to 1991) the currency was held at constant exchange rate of \$1 USD to 2.07 Birr (see figure 4.4, below).

Figure 4.4. Inflation and the Nominal Exchange Rate of Ethiopia, 1970 to 2011

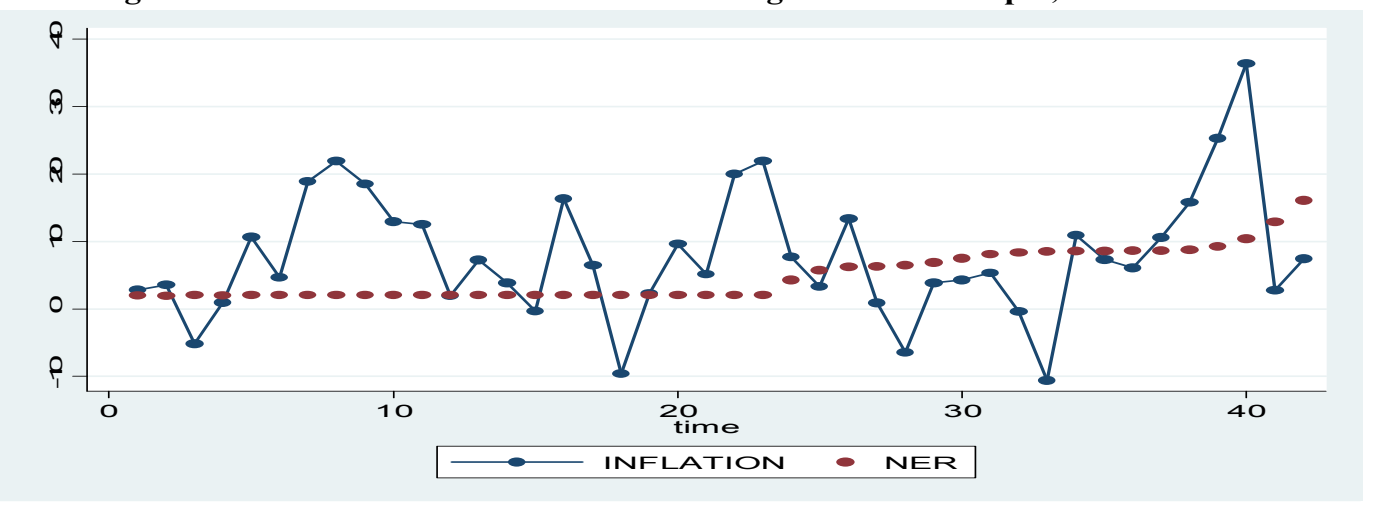

\subsection{DESCRIPTIVE ANALYSIS}

In the empirical analysis, all explanatory variables specified in the model were included. This series were the general Consumer Price Index (CPI), the Broad Money Supply (BMON), the Real Gross Domestic Product(RGDP), the Budget Deficit as percentage of GDP(BDEFI), the Nominal Exchange rate of Birr against US Dollar (NER), the banks and financial institutions average lending rate (IR), the inflation expectation (INFEXP), the Rainfall (RAINFALL) and the International Petroleum Price(PETRPRI). This sub section discussed on the descriptive statistics of the series under study period.

Table 4.1 Descriptive analysis

\begin{tabular}{|c|c|c|c|c|c|c|c|c|}
\hline \multicolumn{9}{|c|}{ Sample: 1970-2011 } \\
\hline \multicolumn{9}{|c|}{ Observations:42 } \\
\hline & LCPI & LBMON & LRGDP & LDEFICIT & LNER & LINFEXP & LRAINFALL & LPETRPRI \\
\hline Mean & 5.457796 & 8.880309 & 10.89372 & 7.048674 & 1.355668 & 0.005886 & 5.089005 & 5.951305 \\
\hline Median & 5.35720 & 8.807172 & 10.77609 & 7.192857 & 0.847900 & 0.061234 & 5.096691 & 5.792004 \\
\hline Maxim & 6.890151 & 11.88709 & 11.97731 & 8.883377 & 2.779924 & 0.310343 & 5.318251 & 7.296047 \\
\hline Minim & 4.136328 & 5.793014 & 10.23474 & 5.339939 & 0.727549 & -2.666381 & 4.841566 & 5.239516 \\
\hline Std.dv & 0.878357 & 1.573779 & 0.464146 & 1.173320 & 0.705720 & 0.442253 & 0.124687 & 0.568674 \\
\hline Skew & 0.033536 & 0.039439 & 0.771970 & -0.00134 & 0.408369 & -5.704228 & 0.123878 & 0.825601 \\
\hline Kurosi & 1.76609 & 2.004781 & 2.812189 & 1.691695 & 1.408369 & 5.06913 & 2.530651 & 2.766628 \\
\hline
\end{tabular}

\subsection{ECONOMETRIC ANALYSIS}

\subsubsection{UNIT ROOT TEST RESULT}

The study used the test equation of pure random walk for natural logarithm of inflation expectation (LINFEXP) and the natural logarithm of rainfall (LRAINFALL). Therefore, it is better to test with drift. The rest of all variables like most macroeconomic variables, change much over time. Therefore the study employed these series on test equation of drift and trend together. 
Table 4.2 Unit root test result in first difference.

\begin{tabular}{|l|c|c|c|}
\hline VARIABLE & ADF Test & \multicolumn{2}{|l|}{} \\
\hline & None & Intercept & intercept and trend \\
\hline LCPI & -4.174153 & -4.118473 & $-4.107482^{* * *}$ \\
\hline LBMON & -0.434155 & -2.790171 & $-3.996471^{* *}$ \\
\hline LRGDP & -4.341318 & -5.598281 & $-5.942201^{* * *}$ \\
\hline LBDEFI & -9.036420 & -6.185112 & $-6.093992^{* * *}$ \\
\hline NER & -3.189237 & -3.829760 & $-3.939129^{* * *}$ \\
\hline LIR & -3.996665 & -3.956305 & $-3.897756^{* *}$ \\
\hline LINFEXP & -7.264314 & -7.141094 & $-7.141094^{* * *}$ \\
\hline LRAINFALL & -6.981714 & -6.894907 & $-6.809438^{* * *}$ \\
\hline LPETRPRI & -4.106819 & -4.578557 & $-4.570303^{* * *}$ \\
\hline
\end{tabular}

Critical value of reject the null hypothesis is based on Mackonen p-value (1996)

* rejecting the null hypothesis at 10\% level of significance

** rejecting the null hypotheisis of unit root at $5 \%$ level of significance

*** rejecting the null hyptotesis of unit root at $1 \%$ level of significance

Table 4.2 illustrates that the null hypothesis of no unit roots for all the time series are rejected at their first differences since the ADF values are less than critical value at $5 \%$ level of significances or $t$-statistics are larger negative number which their absolute value are greater than the absolute values of critical values at $5 \%$ significance level. However, the application of the ADF test for the natural logarithm of GDP revealed that this variable is stationary in both its levels and its first difference on pure random walk. In this case, LINFEXP does not need differencing, just the logarithmic transformation. Specifically, the ADF test indicates that we fail to reject the null of unit root of or all variables even at $10 \%$ level of significant except the natural logarithm of budget deficit, stationary at $10 \%$ and $5 \%$ but not at $1 \%$ level.

\section{VAR ESTIMATION RESULT}

Based on the nature of macroeconomic variables, dynamic and feedback relationship, modeling the determinants of inflation in Ethiopia is by VAR approach. The VAR model assuming all the variables in the model are endogenously treated. However, this study assumes priori that the natural logarithm of rainfall and the gasoline price in international market are treated exogenously. The LRAINFALL is determined naturally whereas the Ethiopian's influence in the international market to settled the price of petroleum is insignificant or almost zero.

Table (4.3) the result of the VAR estimation

. varsoc lcpi lbmon lrgdp lbdefi lner lir linfexp, maxlag(2) exog(lpetrpri lrainfall)

\section{Selection-order criteria}

Sample: 1975 - 2011

Number of obs

$=$

37

\begin{tabular}{|r|cccccccc|}
\hline $\operatorname{lag}$ & $L I$ & LR & df & $p$ & FPE & AIC & HQIC & SBIC \\
\hline 0 & -87.414 & & & & $8.3 e-07$ & 5.86022 & 6.18255 & 6.77452 \\
1 & 140.824 & 456.48 & 49 & 0.000 & $5.6 e-11$ & -3.82833 & -2.75387 & $-.780643 *$ \\
2 & 207.399 & $133.15 *$ & 49 & 0.000 & $3.3 e-11 *$ & $-4.77835 *$ & $-2.95178 *$ & .402711 \\
\hline
\end{tabular}

Endogenous: lcpi lbmon lrgdp lbdefi lner lir linfexp

Exogenous: lpetrpri lrainfall _cons

The VAR result after modeling the Ethiopian price level and its main determinants, I expected that the results for all Variables including the exogenous series. However, the natural logarithm of the Nominal Exchange Rate (LNER) is inconsistent with our expectation. I expect positive relationship between the LCPI and LNER but the reverse is true in reality, LNER has negative effect on inflation. This can be happened in some cases especially in higher government intervening market. It should be noted that government administered a number of crucial goods in Ethiopia. The goods like Electricity supply, Water supply as ( Kibrom T., 2008) indexed as administered price of the government. A great part of administered goods are imported goods such as Wheat, Edible oil, Crude oil. This action has distorted the measure of pass through of Exchange rate changes. Price administration may diminish the positive impact of exchange rate depreciation on inflation pressure. This finding is contradicted with previous studies case of Ethiopia (see; for example, Kibrom T., 2008; IMF, 2008; Asayehegn D., 2008; Solomon; 2012) but in line with (Thanh B.T.K., 2008) modeling the determining factors of Vietnam's inflation, similar nature of 
economy with Ethiopia.

\section{COINTEGRATION ANALYSIS}

Johansen's approach derives two likelihoods estimators for the co-integration rank, a Trace test and Maximum eigen value test. The cointegration rank $(\mathrm{R})$ can be formally tested with the trace and the maximum eigen value statistics. Table 4.3 demonstrates that the trace statistics either reject the null hypothesis of no cointegration among the variables or does not reject the null hypothesis that there is one cointegrating relation between the variables. Start by testing Ho: $r=0$. If it rejects, repeat for $\mathrm{Ho}=\mathrm{r}=1$. When a test is not rejected, stop testing and there and that value of $\mathrm{r}$ is commonly estimate of the number of cointegrating relations. In this test, Ho $=r=1$ is not rejected at $5 \%$ level of significance $(133.6124<136.61)$.

\begin{tabular}{|c|c|c|c|c|c|c|c|}
\hline \multirow[t]{2}{*}{$\begin{array}{l}\text { Trend: } \\
\text { Sample: }\end{array}$} & $\begin{array}{l}\text { rend } \\
1971-\end{array}$ & Johan & $n$ tests for & cointegratio & Number & \multirow[t]{2}{*}{$\begin{array}{r}\text { of obs }= \\
\text { Lags }=\end{array}$} & $\begin{array}{r}41 \\
1\end{array}$ \\
\hline & & & & & $5 ㅇ ㅡ ㅇ$ & & \\
\hline maximum & & & & trace & critical & & \\
\hline rank & parms & $L L$ & eigenvalue & statistic & value & & \\
\hline 0 & 16 & 154.80345 & . & 205.8547 & 170.80 & & \\
\hline 1 & 31 & 190.92462 & 0.82830 & $133.6124 *$ & 136.61 & & \\
\hline 2 & 44 & 212.6302 & 0.65313 & $90.2012^{-}$ & 104.94 & & \\
\hline 3 & 55 & 227.01419 & 0.50424 & 61.4332 & 77.74 & & \\
\hline 4 & 64 & 239.61863 & 0.45928 & 36.2244 & 54.64 & & \\
\hline 5 & 71 & 246.30925 & 0.27846 & 22.8431 & 34.55 & & \\
\hline 6 & 76 & 252.96259 & 0.27715 & 9.5364 & 18.17 & & \\
\hline 7 & 79 & 255.95079 & 0.13564 & 3.5600 & 3. 74 & & \\
\hline 8 & 80 & 257.73081 & 0.08317 & & & & \\
\hline
\end{tabular}

In other words, this trace test result does not reject the null hypothesis that these eight variables are not cointegrated. The final number of cointegrated vectors with one lag is equal to one i.e. $\operatorname{rank}(\pi)=1$. Since, the rank is equal to 1 which is more than zero and less than the number of variables. Nevertheless, I will proceed to estimate the VECM.

THE VECM

When two variables are cointegrated there is long run relationship between the seven Variables with their lag values, 1.

$$
L C P I-4.62 L B M O N+1.925 L B D E F I-4.33 L I R+6.59 L R G D P+4.77 l N E R+4.53 L R A I N F A L L=
$$
$\varepsilon_{t}$

This equations shows the long run relationship of inflation with Broad Money Supply, Budget Deficit proportionate of GDP, Banks and financial institutions Lending Rate, Real GDP, Nominal exchange rate and the rainfall of Ethiopia. The international petroleum price is excluded from the above model by fact negative relationship between inflation and international gasoline price but insignificantly. The expected inflation is run in test type as pure random walk series, and the VECM assumed it as exogenous.

The error correction terms measures deviations of the series from the long run equilibrium relations. The coefficient of broad money supply has a positive long run relation with inflation with high level of significance. The coefficient of Real GDP also has a negative effect of inflation in Ethiopia.

The results are interpreted as a one percent increase in Broad Money Supply increases the inflation rate of Ethiopia by 4.62 percent in the long run, keeping other determinants constant. Again, a one percent decrease in Real GDP increases the inflation rate by 6.59 percent in the long run, citrus paribus. One important result we should noted here is that, Ethiopia's economy is highly agrarian and it accounts more than 45 percent of the national income is from the agricultural sector. The Broad Money Supply is highly significant than the Real GDP whereas Real GDP has highest magnitude. Therefore, it is difficult to conclude the phenomena leads either by Real GDP or from Broad Money supply. The aggregate result of the money market and the summative strength of the structural condition may give as which factor contributes more of the inflationary pressure of Ethiopia.

The deficit budget has a negatively affecting the domestic inflation. In the long run the expenditure of the government may on infrastructures; the printing money has a power to generate income and covering the expenditure. This is consistent with the fact in Ethiopia recently such as construction of dams, roads, power generating stations and the railway constructions. In the long run, a one percent increase in the budget deficit leads to 1.92 percent decline in inflation rate per annum, holding other determinants of inflation in Ethiopia between 1970 to 2011 not changing. In the long run, a one percent increase in Banks and Financial institutions lending rate soaring inflation rate of Ethiopia by 4.32 percent by citrus paribus assumption. This factor also adding one information that the monetary conditions have better strength to determine the domestic price hike of Ethiopia under the study period. 
Another structural variable modeling to determine the inflation pressure of Ethiopia is Rainfall. In the long run, a one percent increase in the amount of rain in the economy leads to fall inflation rate by 4.53 percent, keeping all other determinants of inflation being constant. To conclude, in the long run inflation is more described by monetary factor than structural conditions in aggregate. But, who lead who follow analysis is important than modeling the variable in VAR to absolutely identifying which factor leads the Ethiopian inflation situation is better described by the model, Diag(1994), which is out of the scope of the study. But it invites for further careful research. This gap may intervene by another study or researcher. And another important point from the above result is that petroleum price has statistically insignificant in the long run.

The short run dynamics of the determinants of inflation over 1970 to 2011 is revealed by the Vector Error Correction Model presented. The R-squared of the model shows that 45.71 percent of variation in the Consumer Price Index is explained by the combined effect of the variables in the model. In the short run, the previous year consumer price index has a positive 22.16 percent insignificant factor for the inflationary pressure. Banks and financial institutions average lending rate has positive short run effect but marginally statistically insignificant to affect the inflation pressure. This may due to the failure of the market to determine the average lending rate of the economy rather it determined by the government. This takes longer time to affect the price level of the economy.

\section{Recommendation}

Inflation in Ethiopia is structural. Hence avoiding the structural bottleneck of the economy should be given priority. Most importantly structural bottlenecks of the agricultural sector shall be removed, but at the same time removing the bottlenecks of the other sectors also is important.

In the long run inflation in Ethiopia is also a monetary phenomena is more described by monetary factor than structural conditions in aggregate. But it invites for further careful research.

Though budget deficit has been found to be in significant making a detailed study of the impact of deficit on inflation should be done. Therefore further study on the impact of deficit on inflation must be done.

Even if Gas Oil price has been found to be insignificant in affecting consumer price index in Ethiopia in the findings of the study, it is impossible to make conclusions about the impact of international price developments on Ethiopian consumer price index based on Gas Oil prices. So it is important to make a detailed analysis of the impact of international prices on Ethiopia CPI.

In governments finance their wars by borrowing and printing money, rather than presenting a bill to the legislatures directly in the form of higher taxes. This is especially the case if the tax-base is rather weak and/or the government in question does not have the support of its people. Therefore appropriate measurement can be taken by the government.

The huge volume of foreign money entering the country bolsters the demand for goods and services, and as a result increases the risk of inflation unless their impact is thwarted by raising interest rates on treasury bills to ease their inflationary pressures. Therefore the government take measurement on this issue.

\section{Reference}

AfDB (2011); country strategy paper2011-2015,Federal Democratic Republic of Ethiopia african Development Bank G group.

Alemayehu G. and Kibrom T., 2008 The Galloping Inflation in Ethiopia: A Cautionary Tale for Aspiring 'Developmental States' in Africa. Department of Economics Addis Ababa University October, 2008.Dlamini acute,

Dlamini Armstrong and Tsidi Nxumalo (2001). A co integration Analysis of inflation in Swaziland.

Ethoipian economic Association/ Ethiopian economic policy research institute(2001). Report on the Ethiopian economy volume V 2005/06. Addis Ababa, Ethiopia.

Barungi , 1997 , Kotwal , 1987 Exchange rate policy and inflation the case of Uganda.

Bayo F.,(2004); The nature of inflation in Malawi up to the early 2000

Belay W. Getachew. (1996). Economic Analysis of inflation from the short run and long run perspectives (the case of Ethiopia). Vienna, Austria.

Birouk t. et al. 2010, The source of the recent inflationary experience in Ethiopia.

Bynoe D.L., et.al. (2008) and Broto C. (2008) Impacts of the Trilemma Policies on Inflation.

Dlamini Armstrong and Tsidi Nxumalo (2001). A co integration Analysis of inflation in Swaziland.

Ethoipian economic Association/ Ethiopian economic policy research institute(2001). Report on the Ethiopian economy volume V 2005/06. Addis Ababa, Ethiopia.

Engle, R. F. and Granger, C. W. (1987): "Cointegration and Error Correction: Representation, Estimation and Testing”. Econometrica, 55,251-276.

Friedman, M. (1960, March). A Progress for Monetary Stability, New York. Friedman, M. (1971). The Role of Monetary Policy. Journal of Political Economy, Vol. 58, pp. 1-17.

Friedman and Schwartz (1968), Inflation Targeting in a St. Louis Model of the 21 st Century. 
Gardner Ackley (1961, pp: 502), Survey of Inflation Theory, The American Economic Review, Vol. 53, No. 4 (Sep., 1961), pp. : 502

Harry G. Johnson (1972, pp: 9) "The Costs of Inflation", American Economic Review, 1972, pp: 9

IMF. (2008). Federal Democratic Republic of Ethiopia: 2008 Article IV Consultation Staff Report. IMF Country Report 08/264. Washington DC: International Monetary Fund.

Johansen, S. (1991): "Estimation and Hypothesis Testing of Cointegration Vectors in Gaussian Vector Autoregressive Models" .Econometrica, 59, 1551-1580.

Kemmerer (1942, "The AB C of Inflation", with Particular Reference to Present-day Conditions in the United States.

Khan M.S. and Knight M.D.,1982 "Inflation in Pakistan: money or wheat, March 1982; SBP-Research Bulletin Conference Volume, 2006.

Keynes (1940," inflation and making of Australian", Macroeconomic stability.

Loening, L.J., Durevall, D.and Birru, Y.A. (2009): "Inflation Dynamics and Food Prices in anAgricultural Economy: The Case of Ethiopia," Working Paper 347. Gothenburg:University of Gothenburg.

Lutkepohl, H. (1991): Introduction to Multiple Time Series Analysis .Springer-Verlag, Berlin.

Ministry of Finance and Economic Development. (2007/08). Annual Reports, various issues.

MoFED(2012): ministry of finance and economic development annual report on macroeconomic developments.

Teshome A. Sources of Inflation and Economic Growth in Ethiopia: Descriptive Analysis.

Teslim (1982) The impact of disasters on inflation.

Unsal et. al. (2011) Drivers of Inflation in Sub-Saharan Africa.

Walgenbach, P. H., Norman ,E. Dittrich, and. Hanson ,E. I (1973):Financial Accounting, New York: Harcourt Brace Javonovich, Inc. Page 429 